\title{
Flow cytometric analysis of the heat shock protein 60 expressed on the cell surface of Helicobacter pylori
}

\author{
HIROYUKI YAMAGUCHI, TAKAKO OSAKI*, HARUHIKO TAGUCHI, TOMOKO HANAWA, \\ TOMOKO YAMAMOTO and SHIGERU KAMIYA \\ Department of Microbiology and *Division of Flowcytometry, Kyorin University School of Medicine, Mitaka, \\ Tokyo 181, Japan
}

\begin{abstract}
The expression of a 60-kDa heat shock protein (HSP60) on the cell surface of Helicobacter pylori was analysed by flow cytometry with polyclonal antibody directed to HSP60. All 13 strains of $H$. pylori examined expressed HSP60 on the cell surface, although the intensity of expression was different among the strains and depended on culture conditions. There was a correlation between the intensity of HSP60 expressed on the cell surface and the rate of adherence to human gastric carcinoma cells (MKN45) by $H$. pylori, but not with urease activity and production of vacuolating toxin. By flow cytometric analysis with monoclonal antibody (MAb) $3 \mathrm{C8}$ against $\mathrm{HSP60}$, the reactive epitope in the HSP60 of $\mathrm{H}$. pylori was detected on the surface of MKN45 cells. Furthermore, it was shown that gastric epithelial cells were positively stained with MAb $3 \mathrm{C8}$ in one of two biopsy specimens examined. These results suggest that there is a common epitope showing homology between $H$. pylori HSP60 and human gastric epithelial cells.
\end{abstract}

\section{Introduction}

Helicobacter pylori is a gram-negative, spiral-shaped micro-aerophilic organism that colonises the human gastric mucosa $[1,2]$ and infection with $H$. pylori may be a permissive factor in peptic ulcer disease [3-5]. Various potential virulence factors have been identified in $H$. pylori, including flagella $[6,7]$, adhesin [8], urease $[9,10]$, vacuolating toxin $[11,12]$ and the toxin that inhibits secretion of gastric acid in vitro $[5,13]$. However, the pathogenic mechanism by which $H$. pylori persists in the stomach is not fully understood.

Heat shock proteins (HSPs), induced by various environmental stresses such as temperature change, inflammation, viral infection, malignant transformation, irradiation, heavy metals, ethanol and anoxia, are highly conserved proteins found not only in prokaryotic but also in eukaryotic cells [14-16]. The HSP60 family of chaperonins such as GroEL of Escherichia coli and the $65-\mathrm{kDa}$ immunodominant antigen of Mycobacterium spp. is thought to facilitate folding, unfolding and translocation of polypeptides, as well as the assembly and disassembly of oligomeric protein complexes [17-20]. H. pylori HSP60 is thought to be associated with urease, one of the putative virulence

Received 6th Oct. 1995; revised version received 24 Feb. 1996; accepted 26 Feb. 1996.

Corresponding author: Dr H. Yamaguchi. factors of $H$. pylori $[21,22]$. An understanding of the relationship between $H$. pylori HSP60 and pathogenicity of $H$. pylori in the induction of gastritis might be important for resolution of the mechanism by which $H$. pylori persists in the stomach $[23,24]$. Recently, it has been demonstrated that human infection with $H$. pylori could stimulate an autoimmune response, possibly directed against HSPs expressed by stressed gastric epithelial cells $[25,26]$.

In the present study, the expression of HSP60 on the cell surface of various $H$. pylori strains was examined by flow cytometry and the relationships between the expression of the HSP60, adherence to human gastric carcinoma cells, urease activity and production of vacuolating toxin were also investigated. A crossreaction between HSP60 of $H$. pylori and human gastric carcinoma cells was also analysed and human gastric biopsy specimens were used for immunostaining with monoclonal antibody (MAb) to HSP60.

\section{Material and methods}

Bacterial strains and growth conditions

H. pylori strains used in this study were: TK1025, TK1028, TK1029, TK1030, TK1042, TK1046, TK1054, TK1302, TK1308, TK1309, TK1311 and TK1313, which were isolated from gastric biopsy samples from patients as described previously [27]; 
H. pylori NCTC 11638 was kindly provided by Dr T. Ito (Tokyo Metropolitan Research Laboratory of Public Health). For the analysis of the rate of HSP60 expression on the cell surface of $H$. pylori, bacteria were cultured either in Brain Heart Infusion (BHI) Broth (Difco) containing fetal calf serum (FCS; Wako Pure Chemical Ltd, Osaka, Japan) $5 \%$ or on BHI agar (Difco) with defibrinated horse blood 5\% (BHI-blood plate) in an atmosphere consisting of $\mathrm{O}_{2} 5 \%, \mathrm{CO}_{2}$ $10 \%, \mathrm{~N}_{2} 85 \%$ for 4 days at $37^{\circ} \mathrm{C}$. These cultures were centrifuged at $3000 \mathrm{~g}$ for $15 \mathrm{~min}$ and the cells were resuspended in Hanks's Balanced Salts Solution (HBSS; Gibco Laboratory, New York, USA) containing gelatin (Sigma) $0.1 \%$ (HGS) for flow cytometric analysis. The other part of the suspension was used for SDS-PAGE. For the analysis of cross-reaction between $H$. pylori HSP60 and human gastric carcinoma cells, bacteria cultured on BHI-blood agar were used. Table 1 shows the characteristics of the $H$. pylori isolates used in the present study.

\section{Urease activity}

Urease activity was measured by the method described previously by Kamiya et al. [28]. Urease activity was quantified by the ammonia-test WAKO (Wako Pure Chemical Ltd) according to the amount of ammonia produced. One hundred and seventy-five $\mu \mathrm{l}$ of sonicated bacteria $(100 \mu \mathrm{g} / \mathrm{ml})$ were added to $25 \mu \mathrm{l}$ of $200 \mathrm{mM}$ phosphate buffer ( $\mathrm{pH} 7.4$ ), $25 \mu \mathrm{l}$ of $1 \mathrm{mM}$ ethylenediamine tetraacetic acid, disodium salt (Dojin Ltd, Kumamoto, Japan), and $25 \mu \mathrm{l}$ of substrate containing $4 \mathrm{M}$ urea in the phosphate buffer with bovine serum albumin (Sigma) $2.5 \% \mathrm{w} / \mathrm{v}$. The mixture was incubated at $25^{\circ} \mathrm{C}$ for $20 \mathrm{~min}$. The reaction was stopped by the addition of $1.0 \mathrm{ml}$ of sodium tungstate $5 \% \mathrm{w} / \mathrm{v}$ to the test sample and the mixture was then centrifuged at $3000 \mathrm{rpm}$ for $15 \mathrm{~min}$. The amount of ammonia in the supernatant fluid was quantified by the commercially available ammonia assay.

\section{Production of vacuolating toxin}

Production of vacuolating toxin by the strains was measured by the method described previously by Kamiya et al. [12]. A rabbit kidney cell line (RK13) was used for the cytotoxicity assay to detect the vacuolating toxin. The serially diluted culture filtrate of H. pylori grown in BHI broth containing FCS $5 \%$ in a micro-aerophilic atmosphere for 4 days at $37^{\circ} \mathrm{C}$ was added into the culture medium for RK13 cell for $24 \mathrm{~h}$ at $37^{\circ} \mathrm{C}$. The appearance of cytoplasmic vacuolation in RK13 cells was observed microscopically. The titre of vacuolating toxin was determined as the highest dilution of the culture filtrate that showed vacuolation of $>10 \%$ of cells.

\section{Cell culture}

Human gastric carcinoma cells (MKN28, MKN45 and KATO III) were obtained from the Japanese Cancer Research Resources Bank (JCRB). They were grown at $37^{\circ} \mathrm{C}$ in RPMI 1640 containing FCS $10 \%$ in an atmosphere containing $\mathrm{CO}_{2} 5 \%$.

\section{Preparation of antiserum against bacterial HSP60}

Bacterial HSP60 was purified from Yersinia enterocolitica O3 (strain ZM20) by immuno-affinity chromatography with a specific MAb, 1A4, against $Y$. enterocolitica HSP60 as reported previously [29]. Antibacterial HSP60 serum (anti-HSP60) was obtained from rabbits immunised with the purified HSP60 from Y. enterocolitica.

Table 1. Characteristics of $H$. pylori strains

\begin{tabular}{lcrcc}
\hline Strain & $\begin{array}{c}\text { Gastroendoscopic } \\
\text { diagnosis }\end{array}$ & \multicolumn{2}{c}{ Urease activity $(\mu \mathrm{g} / \mathrm{dl})^{*}$} & $\begin{array}{c}\text { Vacuolating } \\
\text { toxin }^{\S} \\
\text { titre }\end{array}$ \\
\cline { 3 - 4 } TK1025 & Gi & broth $^{\dagger}$ & agar $^{\ddagger}$ & ND \\
TK1028 & DU & 86 & 463 & ND \\
TK1029 & GU, IM, At, SMT & 66 & 2187 & 8 \\
TK1030 & GP, At & 177 & 347 & 4 \\
TK1042 & GU, DU, IM & 77 & 384 & ND \\
TK1046 & GP & 157 & 697 & ND \\
TK1054 & At & 391 & 299 & 2 \\
TK1302 & DU & 188 & 526 & 4 \\
TK1308 & GCa & 83 & 449 & 16 \\
TK1309 & GU & 188 & 583 & 1 \\
TK1311 & DU & 97 & 659 & ND \\
TK1313 & GCa & 68 & 411 & 2 \\
NCTC11638 & Gi & 120 & 286 & ND \\
\hline
\end{tabular}

Gi, gastritis; DU, duodenal ulcer; GU, gastric ulcer; IM, intestinal metaplasia; At, atrophy; SMT, submucosal tumor; GP, gastric polyp; GCa, gastric cancer; ND, not detected.

*Urease activity was quantified according to the amount of $\mathrm{NH}_{3}$ produced as described in the text.

tUrease activity of the strains cultured in BHI broth containing FCS.

${ }^{\ddagger}$ Urease activity of the strains cultured on BHI-blood agar.

${ }^{\S}$ Vacuolating activity was measured by the cytotoxity assay with RK13 cells as described in the text. 


\section{Monoclonal antibody}

$\mathrm{MAb} 3 \mathrm{C} 8$ to $Y$. enterocolitica HSP60, showing reactivity with HSP60 from a wide range of bacteria and human cell lysate, was prepared as described previously [29].

\section{Flow cytometric analysis}

Flow cytometry was performed by the method described by Osaki et al. [30]. H. pylori strains ( $c$. $5 \times 10^{7} \mathrm{cfu}$ ) were mixed with $200 \mu \mathrm{l}$ of either polyclonal anti-HSP60 antibody diluted 1 in 50 or MAb $3 \mathrm{C} 8(100 \mu \mathrm{g} / \mathrm{ml})$ in $\mathrm{HGS}$, and then incubated for $30 \mathrm{~min}$ at $4^{\circ} \mathrm{C}$. Similarly, the cultured cells $\left(5 \times 10^{4}\right)$ of MKN45, MKN28 or KATO III were mixed with $200 \mu \mathrm{l}$ of the solution of polyclonal antibody to HSP60 or MAb $3 \mathrm{C} 8(100 \mu \mathrm{g} / \mathrm{ml})$ in HGS followed by incubation for $30 \mathrm{~min}$ at $4^{\circ} \mathrm{C}$. The cells were washed twice with HGS and fluorescent isothiocyanate (FITC)-conjugated goat anti-rabbit or mouse immunoglobulin $G$ (Capel Research Products, Durham, USA) diluted to 1 in 20 in HGS was added. The cells were washed twice with HGS and resuspended in $300 \mu \mathrm{l}$ of PBS for flow cytometry. An EPICS-CS flow cytometer (Coulter Electronics, Hialeah, USA) was used for the measurement of fluorescence intensity. Fluorescence data were obtained in a logarithmic mode on a 256-channel scale. The mean fluorescence channel was calculated according to the fluorescence intensity of $>3000$ individual cells. The results were shown as the positive percentage of fluorescent cells calculated from fluorescence frequency distribution histograms.

\section{Adherence assay}

The adherence assay with human gastric carcinoma cells (MKN45) for $H$. pylori strains was performed by the method described by Osaki et al. [30]. MKN45 cells and $H$. pylori were incubated at $37^{\circ} \mathrm{C}$ for $1 \mathrm{~h}$ in a $1.5 \mathrm{ml}$ tube with gentle shaking. Non-adherent bacteria were removed by centrifugation with $9 \mathrm{ml}$ of sucrose $15 \%$ solution. The cells were washed once with HGS and then incubated for $30 \mathrm{~min}$ on ice with anti- $H$. pylori serum diluted 1 in 100 . The cells were washed twice with HGS and stained with FITC-conjugated goat anti-rabbit IgG diluted in 1 in 20 . The cells were washed twice with HGS and resuspended in $300 \mu \mathrm{l}$ of HGS for the flow cytometric adherence assay. An EPICS-CS flow cytometer was used to measure the number of bacteria adhering to MKN45 cells. The results were expressed as the mean channel of fluorescent cells showing the highest intensity into fluorescence frequency distribution histograms.

\section{SDS-PAGE and immunoblotting}

SDS-PAGE with acrylamide $10 \% \quad \mathrm{w} / \mathrm{v}$ gel was performed as described by Laemmli [31]. Bacterial cells and human gastric carcinoma cells were harvested and suspended in $100 \mu \mathrm{l}$ of the lysis buffer $(0.4 \mathrm{mM} 2-$ mercaptoethanol, Nonidet P-40 $3.2 \% \mathrm{v} / \mathrm{v}$ ), lysed by seven freeze-thaw cycles (frozen at $-80^{\circ} \mathrm{C}$ and thawed at $37^{\circ} \mathrm{C}$ in a water-bath, each for $5 \mathrm{~min}$ ). Cell lysates $(100 \mu \mathrm{l})$ were heated for $5 \mathrm{~min}$ at $100^{\circ} \mathrm{C}$ in sample buffer $(0.00625 \mathrm{M}$ Tris- $\mathrm{HCl}, \mathrm{pH} 6.8$, containing SDS $2 \% \mathrm{w} / \mathrm{v}$, glycerol $5 \% \mathrm{v} / \mathrm{v}$ and 2 -mercaptoethanol $5 \%$ $\mathrm{v} / \mathrm{v})$. Finally, $10 \mu \mathrm{l}$ of the cell lysates were loaded into each lane. Immunoblot analysis was performed as described by Towbin et al. [32]. After electrophoresis, the separated proteins were transferred to nitocellulose membranes (Schleiher and Schuell, Dassel, Germany) at $0.25 \mathrm{~A}$ overnight. After blocking with gelatin $3 \% \mathrm{w} / \mathrm{v}$ in Tris-buffered saline $(0.15 \mathrm{M} \mathrm{NaCl}, 10 \mathrm{mM}$ Tris- $\mathrm{HCl}$, $\mathrm{pH} 7.4$ ), the membranes were treated for $1 \mathrm{~h}$ with either polyclonal antibody diluted 1 in 1000 or MAb $3 \mathrm{C} 8$ diluted to $100 \mu \mathrm{g} / \mathrm{ml}$ with the blocking buffer. They were then incubated for $1 \mathrm{~h}$ with goat anti-mouse or anti-rabbit IgG peroxidase conjugate diluted 1 in 500 with Tris-buffered saline containing BSA $1 \% \mathrm{w} / \mathrm{v}$. Immunoblots were developed with Tris-saline containing $\mathrm{H}_{2} \mathrm{O}_{2} \quad 0.12 \% \mathrm{v} / \mathrm{v}$ and $1 \mathrm{mM} o$-dianisidine.

\section{Immunohistochemical staining of gastric biopsy specimens with MAb $3 C 8$ to bacterial HSP6O}

Frozen sections ( $4 \mu \mathrm{m}$ thick) obtained from two biopsy specimens were placed on slides. They were fixed in acetone for $5 \mathrm{~min}$ at $4^{\circ} \mathrm{C}$, followed by washing with distilled water. Endogenous peroxidase was blocked by incubation with $\mathrm{H}_{2} \mathrm{O}_{2} \quad 0.1 \% \mathrm{v} / \mathrm{v}$ for $10 \mathrm{~min}$ at room temperature. After washing with phosphate-buffered saline (PBS), pH 7.2, containing Tween $200.2 \% \mathrm{v} / \mathrm{v}$ (Wako Pure Chemical Ltd) (washing buffer), the sections were allowed to react with normal horse serum diluted 1 in 10 with PBS containing skimmed milk (Yukijirushi Nyugyo Co., Tokyo, Japan) $0.1 \% \mathrm{w} / \mathrm{v}$ (PBS-S) for $30 \mathrm{~min}$ to reduce non-specific staining. The sections were treated overnight at $4^{\circ} \mathrm{C}$ with either $\mathrm{MAb} 3 \mathrm{C} 81 \mu \mathrm{g} / \mathrm{ml}$ in PBS-S or the control MAb recognising glucose oxidase derived from Aspergillus niger (Dako Japan Co. Ltd, Kyoto, Japan). After the sections were treated with the washing buffer, they were incubated with biotinylated anti-mouse IgG secondary antibody (Dako Japan Co. Ltd) diluted 1 in 100 with PBS-S. Development by the peroxidase method with avidin-biotinylated enzyme complex and 3, 3'-diaminobenzidine, tetrahydrochloride was performed with the Vectastain ABC kit (Funakoshi Co. Ltd, Tokyo, Japan).

\section{Results}

Immunoblot analysis of $H$. pylori strains with
anti-HSP60 polyclonal antibody

The reactivity of $H$. pylori strains with anti-HSP polyclonal antibody was examined by immunoblot analysis (Fig. 1). HSP60 was detected in all the cell lysates of strains TK1025, TK1028, TK1029, TK1030, 


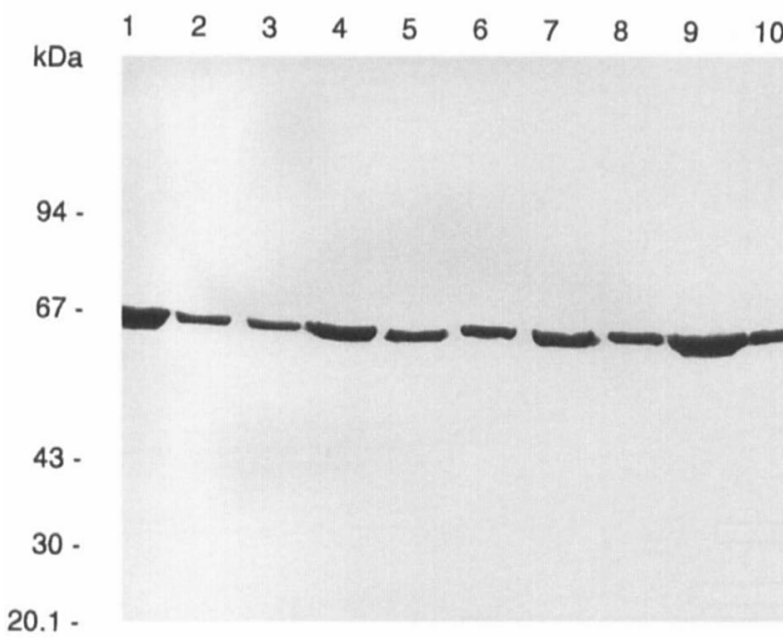

Fig. 1. Immunoblotting patterns of $H$. pylori strains with anti-HSP60 polyclonal antibody directed to $Y$. enterocolitica HSP60. Lanes 1-10 were loaded with cell lysates from the following $H$. pylori strains: 1, TK1025; 2, TK1028; 3, TK1029; 4, TK1030; 5, TK1042; 6, TK1046; 7, TK1054; 8, TK1302; 9, TK1308; 10, TK1309. Bar shows the $60-\mathrm{kDa}$ protein, reacting with anti-HSP60.

TK1042, TK1046, TK1054, TK1302, TK1308 and TK1309 (lanes 1-10). HSP60 was also detected in the cell lysates of other strains (TK1311, TK1313 and NCTC11638; data not shown).

Expression of HSP60 on the cell surface of $H$. pylori

Expression of HSP60 on the surface of $H$. pylori was examined by flow cytometry. Fig. 2 shows the representative patterns of $H$. pylori strains with anti-HSP60, indicating that positive cell percentages of strains TK1029, TK1308 and TK1025 strains were 2.2, 32.8 and $80.6 \%$, respectively. The expression of HSP60 on the cell surface of $H$. pylori was different among the strains used.

Fig. 3a shows the intensity of the expression of HSP60 on the cell surface of $H$. pylori strains cultured either on BHI-blood agar or in BHI broth containing FCS $5 \%$. The expression of HSP60 on the cell surface of $H$. pylori was significantly different, depending on the culture conditions. In general, HSP60 was much more frequently expressed on the cell surface of $H$. pylori strains cultured on BHI-blood agar than in BHI broth containing FCS 5\%, except for strain TK1313.

\section{Correlation between urease activity, production of vacuolating toxin and expression of HSP6O}

Table 1 shows urease and vacuolating activities of strains used in the study. Urease activity of $H$. pylori cultured in BHI broth and on BHI-blood agar was measured; all strains gave positive results. Strain TK1028 cultured on BHI-blood plate had the highest
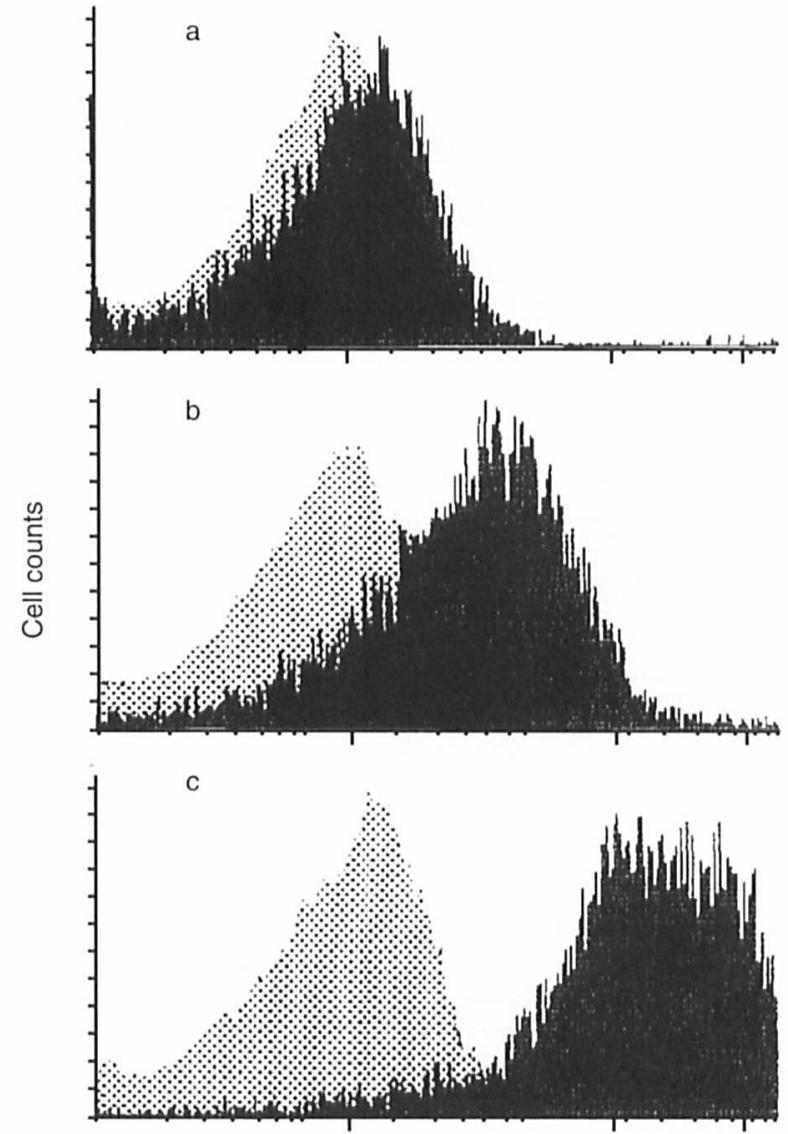

Fluorescence intensity $\left(\log _{10}\right)$

Fig. 2. Representative patterns showing the reactivities of H. pylori strains: a, TK1029; b, TK1308; c, TK 1025 cultured on BHI-blood agar with anti-HSP60 by flow cytometry. $\mathbf{\square}$, pattern of positive cells reacting with antiHSP60; $:$, negative control $H$. pylori strain incubated with non-immune rabbit serum. The positive cell percentage of TK1029 (2.2\%), TK1308 (32.8\%) and TK1025 $(80.6 \%)$ was calculated from the rate of the fluorescence frequency distribution between negatively and positively stained cells.

urease activity among the strains. However, the amount of HSP60 expressed on $H$. pylori strain TK1028 was not high. Although the urease activity of $H$. pylori grown on agar was higher than that grown in broth culture, there was no correlation between the expression of HSP60 on the cell surface and the urease activity of $H$. pylori strains. Vacuolating activity was detected in seven strains (TK1029, TK1054, TK1313, TK1308, TK1030, TK1302 and TK1025) of 13 strains examined. The toxin titre of strain TK1308 (16) was highest. Vacuolating activity was not related to the amount of HSP60 expressed on H. pylori.

\section{Correlation between adherence rate to MKN45 cells and expression of HSP6O}

Fig. $3 \mathrm{~b}$ shows the rate of adherence to human gastric carcinoma MKN45 cells by $H$. pylori strains cultured on BHI-blood agar. All strains adhered to MKN45 cells, although the intensity of adherence of $H$. pylori 


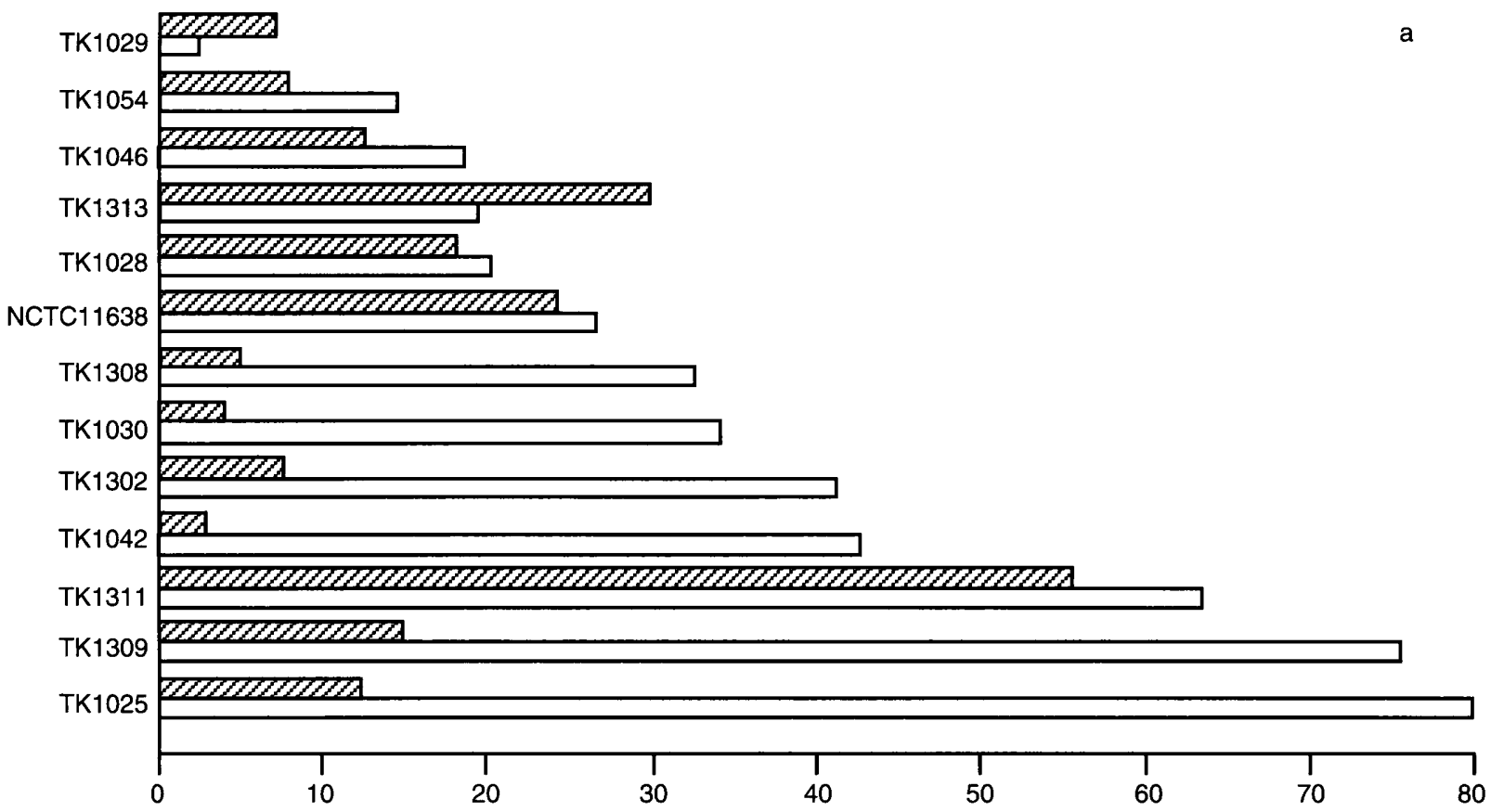

Percentage of cells showing fluorescence

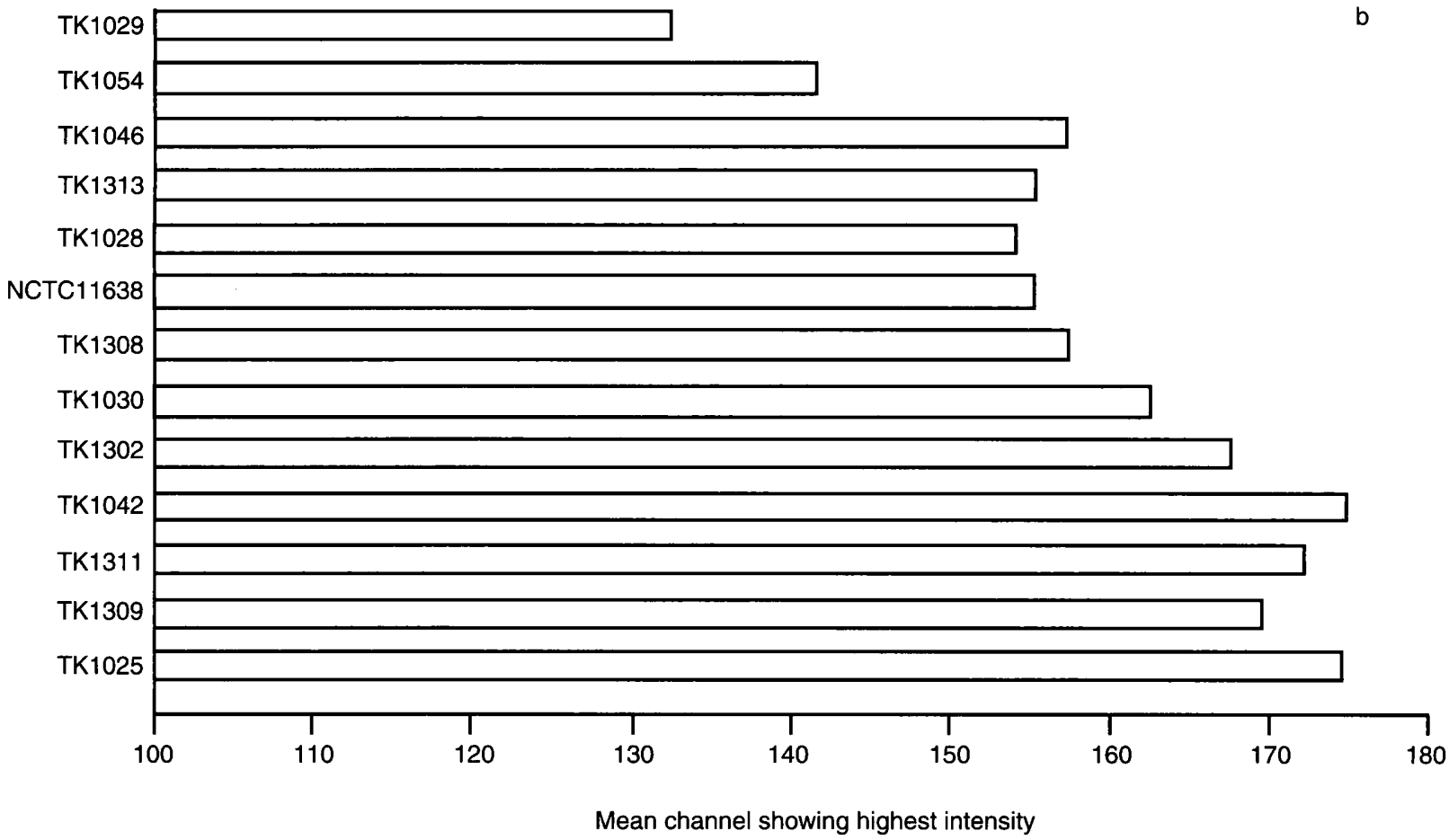

Fig. 3. Expression of HSP60 on the cell surface of $H$. pylori strains and their adherence to human gastric carcinoma cells: a, patterns showing the reactivities of $H$. pylori strains, cultured either on BHI-blood agar or in BHI broth containing FCS 5\%, with anti-HSP60 in flow cytometry; $\square$, intensity of the expression of HSP 60 on the cell surface of H. pylori strain cultured on BHI-blood agar; 5 , intensity of expression in BHI broth containing FCS $5 \%, \mathbf{b}, \square$, adherence of $H$. pylori strains to human gastric carcinoma (MKN45) cells estimated by flow cytometry.

to MKN45 cells was different among the strains studied. Strain TK1029 had the lowest adherence rate, with a mean channel of 132 ; on the other hand, strain TK1025 had the highest adherence rate with a mean channel of 175 . There was a significant correlation between the adherence rate and the expression of HSP60 (correlation index $(r)=0.68)$.
Cross-reaction between H. pylori HSP60 and human gastric carcinoma cells

The possibility of a cross-reaction between $H$. pylori HSP60 and gastric carcinoma cells was investigated by flow cytometry with $\mathrm{MAb} 3 \mathrm{C} 8$ that recognised both bacterial HSP60 and surface antigen of a human B cell 
line [29]. Immunoblotting had shown that MAb 3C8 reacted with $H$. pylori HSP60 (data not shown). The percentages of human gastric cancer cells of MKN45, KATOIII and MKN28 reacting with MAb 3C8 in the flow cytometric analysis were $62.4,18.1$ and $4.9 \%$, respectively, indicating that $\mathrm{MAb} 3 \mathrm{C} 8$ reacted strongly with MKN45 cells (Table 2). Osaki et al. [30] reported previously that the MKN45 cell line is more sensitive in terms of adherence by $H$. pylori than KATOIII or MKN28 cells.

\section{Immunohistochemical staining of gastric biopsy specimens with MAb $3 C 8$}

To observe the profile of human gastric epithelial cells that show cross-reactivity with $H$. pylori HSP60, immunohistochemical staining of gastric biopsy specimens with MAb 3C8 directed to bacterial HSP60 was performed (Fig. 4). Two gastric biopsy samples were obtained from patients with gastric ulcer. Both rapid urease test and isolation of $H$. pylori were positive for these two biopsies. Gastric epithelial cells of one gastric biopsy were positively stained with MAb $3 \mathrm{C} 8$ (Fig. 4a), but not with the negative control MAb directed against glucose oxidase derived from Aspergillus niger (Fig. 4b). In contrast, the other biopsy specimen failed to stain positively with MAb $3 \mathrm{C} 8$ or the MAb to glucose oxidase (data not shown). These results suggested that some gastric epithelial cells express HSP60 homologue on the surface following $H$. pylori infection.

\section{Discussion}

The present study reports the expression of HSP60 on the cell surface of $H$. pylori analysed by flow cytometry. Many investigators previously reported the
Table 2. Reactivity of $H$. pylori and human gastric carcinoma cells with MAb $3 \mathrm{C} 8$ against bacterial HSP60 by flow cytometry*

\begin{tabular}{lc}
\hline Target antigens & Positive cells $(\%)^{\dagger}$ \\
\hline Human gastric carcinoma cells & \\
MKN 45 & 62.4 \\
KATO III & 18.1 \\
MKN 28 & 4.9 \\
H. pylori strains $^{\ddagger}$ & \\
TK1025 & 16.5 \\
NCTC11638 & 14.4 \\
TK1302 & 13.5 \\
TK1311 & 10.3 \\
TK1309 & 7.7 \\
TK1029 & 7.4 \\
TK1046 & 3.9 \\
TK1313 & 2.6 \\
TK1308 & 2.4 \\
TK1028 & 2.3 \\
TK1054 & 1.7 \\
TK1042 & 1.7 \\
TK1030 & 0.8 \\
\hline
\end{tabular}

* Flow cytometry was performed as described in the text. MAb $3 \mathrm{C} 8$ used for the analysis of epitope homology between $H$. pylori HSP60 and human gastric carcinoma cells recognised bacterial HSP60 and human HSP60.

${ }^{\dagger}$ The positive cell percentage, calculated from the fluorescence frequency distribution between negative and positive cells, shows the intensity of the reactivities with MAb $3 \mathrm{C} 8$.

${ }^{\ddagger}$ The strains were cultured on BHI-blood agar.

detection of bacterial surface antigens by various methods [33-35] but not flow cytometry. However, these methods were very complex and the estimation of the results was relatively difficult. As shown in the present study, flow cytometry seems to be useful for the detection of a bacterial surface antigen such as HSP60.

By means of flow cytometry with the polyclonal antibody directed to $Y$. enterocolitica HSP60, the HSP60 expressed on the cell surface of $H$. pylori was detected in all strains studied. On the other hand, the

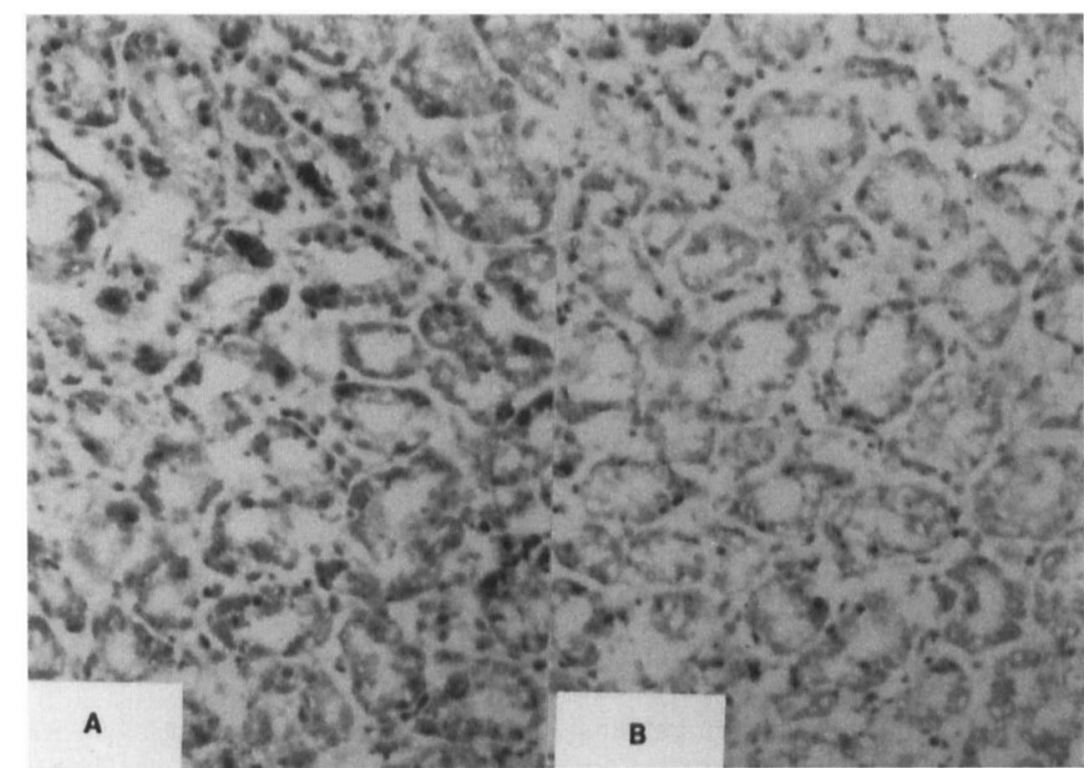

Fig. 4. Immunohistochemical analysis of a gastric biopsy specimen with: A, MAb 3C8 to bacterial HSP60; B, control $\mathrm{MAb}$ to glucose oxidase of $A$. niger. Magnification, $\times 200$. 
values of the positive percentage showing the intensity of expression of $H$. pylori HSP60 on the cell surface of various strains differed, between strains and with different culture conditions. However, in the patterns of immunoblotting with the polyclonal antibody, the HSP60 was equally expressed in all bacterial strains. These results suggest the possibility that the mechanism for expression of HSP60 on the cell surface of $H$. pylori might be different among different strains. The expression of HSP60 on the cell surface in all strains except for TK1313 was higher when they were cultured on BHI-blood agar than when they were cultured in BHI broth. Similarly, urease activity of $H$. pylori strains cultured on BHI blood agar was higher than that of those grown in BHI broth. These results suggest that both expression of HSP60 on the cell surface and production of urease might be influenced by cultural conditions. Haemagglutinating activity expressed by $H$. pylori depends on culture conditions; haemagglutinin was produced when organisms were grown on solid medium but not liquid medium [8]. The difference in the expression of the HSP60 on the cell surface of $H$. pylori strains does not seem to be due to the leakage of HSP60 derived from bacterial cells, as the expression rates of $H$. pylori HSP60 were not significantly different between 2-day and 4-day cultures of $H$. pylori strains - not only on BHI-blood agar but also in BHI broth (data not shown).

It seems that HSP60 of $H$. pylori is a chaperone associating with $H$. pylori urease $[21,22]$. It has been reported recently that HSP60 (GroEL) of $H$. pylori stimulates uptake of $\mathrm{Ni}^{2+}$ into the apoenzyme of urease in co-operation with HSP10 (GroES), resulting in an increase in urease activity [24]. There is a possibility that the amount of urease expressed on a bacterial cell might be associated with the amount of HSP60 expressed on the cell surface of $H$. pylori. However, the results of urease assays indicate that there might be no correlation between the HSP60 expressed on the bacterial cell surface and the amounts of urease produced by $H$. pylori. Furthermore, there was no correlation between the expression of HSP60 and production of vacuolating toxin. However, a significant correlation between the expression of HSP60 and adherence rate of $H$. pylori to MKN45 cells was demonstrated. Further studies are required to clarify whether the bacterial HSP60 acts as an adhesin, or whether the HSP60 is associated with some adhesin molecules.

The present study demonstrated that there was a homologous epitope between $H$. pylori HSP60 and human gastric carcinoma MKN45 cells by flow cytometry with $3 \mathrm{C} 8 \mathrm{MAb}$. The $\mathrm{MAb} 3 \mathrm{C} 8$ reacted not only with bacterial HSP60, including $H$. pylori HSP60, but also with several molecules in human cells [29]. MAb 3C8 was used for flow cytometry in the present study as expression of HSP60 following $H$. pylori infection may stimulate an autoimmune re- sponse in gastric epithelial tissue. The expression of HSP60 on the surface of various carcinoma cells was also examined with polyclonal antibody to HSP60. The degree of positivity in MKN45, KATOIII and MKN28 cells by flow cytometry as 11.9, 2.2 and $14.9 \%$, respectively (data not shown). These results indicate that an epitope homologous to HSP60 molecule is expressed on the surface of gastric carcinoma cells. In addition to cultured gastric carcinoma cells, MAb $3 \mathrm{C} 8$ reacted with the epithelial cells in one of two gastric biopsy specimens obtained from two patients with gastric ulcer in an immunohistochemical assay (Fig. 4). Recently, it has been reported that $H$. pylori infection stimulates an autoimmune response in man, possibly directed against HSPs expressed by stressed gastric epithelial cells $[25,26]$. Therefore, we suppose that the homologous epitope detected between $H$. pylori HSP60 and human gastric cells is an important factor in the induction of gastroduodenal diseases by $H$. pylori, and its pathological significance remains to be clarified.

\section{References}

1. Buck GE, Gourley WK, Lee WK, Subramanyam K, Latimer JM, Dinuzzo AR. Relation of Campylobacter pyloridis to gastritis and peptic ulcer. J Infect Dis 1986; 153: 664-669.

2. Warren J, Marshall B. Unidentified curved bacilli on gastric epithelium in active chronic gastritis. Lancet 1983; 1: 12731275.

3. Bernersen B, Johnsen R, Bostad L, Straume B, Sommer A -I, Burhol PG. Is Helicobacter pylori the cause of dyspepsia? BMJ 1992; 304: 1276-1279.

4. Blaser MJ. Helicobacter pylori and the pathogenesis of gastroduodenal inflammation. $J$ Infect Dis 1990; 161: 626-633.

5. Peterson WL. Helicobacter pylori and peptic ulcer disease. $N$ Engl J Med 1991; 324: 1043-1048.

6. Eaton KA, Morgan DR, Krakowka S. Campylobacter pylori virulence factors in gnotobiotic piglets. Infect Immun 1989: 57: 1119-1125.

7. O'Toole PW, Kostrzynska M, Trust TJ. Non-motile mutants of Helicobacter pylori and Helicobacter mustelae defective in flagellar hook production. Mol Microbiol 1994; 14: 691-703.

8. Evans DG, Evans DJ, Moulds JJ, Graham DY. N-acetylneuraminyllactose-binding fibrillar hemagglutinin of Campylobacter pylori: a putative colonization factor antigen. Infect Immun 1988; 56: 2896-2906

9. Eaton KA, Krakowka S. Effect of gastric $\mathrm{pH}$ on ureasedependent colonization of gnotobiotic piglets by Helicobacter pylori. Infect Immun 1994; 62: 3604-3607.

10. Segal ED, Shon J, Tompkins LS. Characterization of Helicobacter pylori urease mutants. Infect Immun 1992; 60: 1883-1889.

11. Leunk RD, Johnson PT, David BC, Kraft WG, Morgan DR. Cytotoxic activity in broth-culture filtrates of Campylobacter pylori. J Med Microbiol 1988; 26: 93-99.

12. Kamiya S, Kai M, Ozawa A et al. Characteristics of vacuolating toxin produced by Helicobacter pylori. Eur $J$ Gastroenterol Hepatol 1994; 6 Suppl 1: 23-27.

13. Lee A, Fox J, Hazell S. Pathogenicity of Helicobacter pylori: a perspective. Infect Immun 1993; 61: 1601-1610.

14. Born W, Happ MP, Dallas A et al. Recognition of heat shock proteins and gamma-delta cell function. Immunol Today 1990; 11: $40-43$

15. Kaufmann SHE, Schoel B, Wand-Württenberger A, Steinhoff U, Munk ME, Koga T. T-cells, stress proteins, and pathogenesis of mycobacterial infections. In: Kaufmann SHE (ed) T-cell paradigms in parasitic and bacterial infections. Curr Top Microbiol Immunol 1990; 155: 125-141.

16. Young DB. Chaperonins and the immune response. Semin Cell Biol 1990; 1: 27-35. 
17. Creighton TE. Unfolding protein folding. Nature 1991; 352 $17-18$.

18. Ellis RJ. The molecular chaperone concept. Semin Cell Biol 1990; 1: 1-10.

19. Hemmingsen SM, Woolford C, ven der Vies SM et al. Homologous plant and bacterial proteins chaperone oligomeric protein assembly. Nature 1988; 333: 330-334.

20. Yamaguchi $H$, Taguchi H, Katura T, Kumada J, Uekusa $T$, Ogata S. Purification of cross-reacting protein antigen shared by Yersinia enterocolitica and other gram-negative bacteria with monoclonal antibody. Microbiol Immunol 1989; 33: 683688.

21. Evans DJ, Evans DG, Engstrand L, Graham DY. Ureaseassociated heat shock protein of Helicobacter pylori. Infect Immum 1992; 60: 2125-2127.

22. Pérez-Pérez GI, Olivares AZ, Cover TL, Blaser MJ. Characteristics of Helicobacter pylori variants selected for urease deficiency. Infect Immun 1992; 60: 3658-3663.

23. Macchia G, Massone A, Burroni D, Covacci A, Rappuoli R The Hsp60 protein of Helicabacter pylori: structure and immune response in patients with gastroduodenal diseases. Mol Microbiol 1993; 9: 645-652.

24. Suerbaum S, Thiberge J-M, Kansau I, Ferrero RL, Labigne A. Helicobacter pylori hspA-hspB heat-shock gene cluster: nucleotide sequence, expression, putative function and immunogenicity. Mol Microbiol 1994; 14: 959-974.

25. Engstrand L, Scheynius A, Pahlsons C. An increased number of gamma/delta T-cells and gastric epithelial cell expression of groEL stress-protein homologue in Helicobacter pylori-associated chronic gastritis of the antrum. Am J Gastroenterol 1991; 86: 976-980.

26. Negrini R, Lisato L, Zanella I et al. Helicobacter pylori infection induces antibodies cross-reacting with human gastric mucosa. Gastroenterology 1991; 101: 437-445.

27. Kamiya S, Taniguchi I, Yamamoto $T$ et al. Evaluation of rapid urease test for detection of Helicobacter pylori in gastric biopsy specimens. Eur J Epidemiol 1993; 9: 450-452.

28. Kamiya S, Taniguchi I, Yamamoto $\mathrm{T}$ et al. Analysis of intestinal flora of a patient with congenital absence of the portal vein. FEMS Immun Med Microbiol 1993; 7: 73-80.

29. Yamaguchi H, Yamamoto T, Konoeda Y, Taguchi H, Ogata S Epitope homology between bacterial heat shock protein and self-proteins in the host cell. APMIS 1992; 100: 957-962.

30. Yamamoto-Osaki $T$, Yamaguchi $H$, Taguchi $H$, Ogata $S$ Adherence of Helicobacter pylori to cultured human gastric carcinoma cells. Eur J Gastroenterol Hepatol 1995; 7 Suppl 1: S89-S92.

31. Laemmli UK. Cleavage of structural proteins during the assembly of the head of bacteriophage T4. Nature 1970; 227: $680-685$.

32. Towbin H, Staehelin T, Gordon J. Electrophoretic transfer of proteins from polyacrylamide gels to nitrocellulose sheets: procedure and some applications. Proc Natl Acad Sci USA 1979; 76: 4350-4354.

33. Blaser MJ, Hopkins JA, Vasil ML. Campylobacter jejuni outer membrane proteins are antigenic for humans. Infect Immun 1984; 43: 986-993

34. Lohia A, Chatterjee AN, Das J. Lysis of Vibrio cholerae cells: direct isolation of the outer membrane from whole cells by treatment with urea. J Gen Microbiol 1984; 130: 2027-2033.

35. Schnaitman CA. Outer membrane proteins of Escherichia coli IV. Differences in outer membrane proteins due to strain and cultural differences. $J$ Bacteriol 1974; 118: $454-464$. 